TEME, г. XLII, бр. 4, октобар - децембар 2018, стр. 1319-1338

Прегледни рад

Примљено: 1. 12. 2017.

DOI: $10.22190 /$ TEME1804319D

Ревидирана верзија: 10. 5. 2018.

Одобрено за штампу: 12. 6. 2018.

\title{
INDICATORS OF FRAUD IN FINANCIAL REPORTING IN THE REPUBLIC OF SERBIA
}

\author{
Dragomir Dimitrijevic $^{1 *}$, Vladimir Obradović ${ }^{1}$, Sunčica Milutinović ${ }^{2}$ \\ ${ }^{1}$ University of Kragujevac, Faculty of Economics, Kragujevac, Serbia \\ ${ }^{2}$ University of Novi Sad, Faculty of Economics in Subotica, Subotica, Serbia \\ *dimitrijevicd@kg.ac.rs
}

\begin{abstract}
Companies can use various manipulative techniques when preparing generalpurpose financial statements in order to present better financial position and better performance. Fraudulent financial statements can lead their users to wrong decisions and, consequently, cause big losses and distort confidence in the financial reporting system. Therefore, it is important to timely discover and prevent financial reporting frauds. Timely detection of fraud is one of the key tasks of forensic accountants, who should pay attention to fraud indicators, i.e. warning signs of fraud. Warning signs are not evidence of fraud but point to the need for a more detailed investigation. The aim of the research in this paper is to examine whether there are warning signs and to understand the degree of fraud risk in financial reporting by analyzing financial statements of companies in the Republic of Serbia. The research is conducted on a sample of 42 companies. By applying the Beneish model, we find that the general fraud risk is not insignificant. Borrowing activities of companies are identified as a significant source of this risk, while forensic accountants should pay special attention to income recognition and accrual items, i.e., items related to recognition of income and expenses before or after cash inflows or outflows, including depreciation. Higher risk of fraud is identified in manufacturing companies and financial institutions than in trade and service companies. The research results indicate the need to strengthen the mechanisms of financial reporting control in the Republic of Serbia.
\end{abstract}

Key words: financial statements, fraud, fraud indicators, forensic accounting, Beneish model.

\section{ПОКАЗАТЕЉИ ПРЕВАРА У ФИНАНСИЈСКОМ ИЗВЕШТАВАЊУ У РЕПУБЛИЦИ СРБИЈИ}

\footnotetext{
Апстракт

Приликом састављања финансијских извештаја опште намене, а у циљу приказивања што бољег финансијског положаја и што боље успешности, предузећа могу да се послуже разним манипулативним техникама. Лажни финансијски извештаји могу њихове кориснике навести на погрешне одлуке и, сходно томе,
} 
изазвати велике губитке и нарушити поверење у систем финансијског извештавања. Због тога је важно да се благовремено открију и спрече преваре у финансијском извештавању. Благовремено уочавање превара један је од кључних задатака форензичких рачуновођа, који треба да обрате пажњу на показатеље преваре, тј. знакове упозорења на превару. Знакови упозорења нису доказ преваре, већ указују на потребу да се спроведе детаљније испитивање. Циљ истраживања у овом раду јесте да се, путем анализе финансијских извештаја компанија у Републици Србији, испита да ли постоје знакови упозорења и да се спозна степен ризика од превара у финансијском извештавању. Истраживање је извршено на узорку од 42 компаније. Применом Beneish-овог модела, откривено је да општи ризик од превара није безначајан. Задуживање компанија је препознато као значајан извор тог ризика, а форензичке рачуновође треба да обрате посебну пажњу на признавање прихода и обрачунске ставке, тј. ставке повезане са признавањем прихода и расхода пре или након прилива, односно одлива, готовине, укључујући амортизацију. Код производних предузећа и финансијских институција препознат је већи ризик од превара него код трговинских и услужних предузећа. Резултати истраживања указују на потребу за јачањем механизама контроле финансијског извештавања у Републици Србији.

Кључне речи: финансијски извештаји, преваре, показатељи превара, форензичко рачуноводство, Beneish-ов модел.

\section{INTRODUCTION}

Financial statements should faithfully represent the financial position, performance and cash flows of companies. Key preconditions for quality financial reporting are: (1) the existence of high-quality financial reporting standards, and (2) consistent (strict) compliance with these standards (Obradović \& Karapavlović, 2016b, p. 394). Fraudulent financial statements are an integral part of stock market fraud (Stojilković, 2016, p. 115), and, therefore, it is not surprising that large financial scandals that shook the world at the beginning of the 21st century (such as scandals related to the companies "Enron", "WorldCom" and "Parmalat") put the problem of financial reporting quality in forefront and emphasized the importance of rigorous and detailed control and better regulation of financial reporting. It became clear that only the joint efforts of the participants in the financial reporting process (preparers, auditors and users of financial statements, and institutions responsible for financial reporting regulation) can ensure high-quality financial reporting. Prevention and detection of fraudulent financial reporting, which is defined as "the intentional preparation of misleading financial statements" (Needles \& Powers, 2007, p. 8), is imposed as one of the key tasks of the institutions responsible for financial reporting regulation. The need for prevention and detection of fraudulent financial reporting stems from the significance of potential consequences of wrong business decisions (primarily investment and credit decisions) based on false financial statements. 
Preparation of fraudulent financial statements is one of the forms of business frauds. The Association of Certified Fraud Examiners (ACFE) identifies asset misappropriation and corruption as the main categories of business fraud, in addition to the preparation of fraudulent financial statements (Association of Certified Fraud Examiners, 2016, p. 12). Unlike misappropriation of money or some other asset, which is usually done by employees at the detriment of their employers, fraudulent financial reporting is usually associated with management, which in attempts to mislead external persons (Weireich, Pearson \& Churyk, 2010, p. 199). The purpose of fraudulent financial reporting is to present financial position, performance and cash flow in general-purpose financial statements differently than they really are (more or less favorable depending on the specific motives). Frauds in financial statements, as other frauds, involve intent as well as an attempt to conceal. Many frauds are hard to notice. The symptoms are often overlooked or misunderstood.

The subject of research in this paper is indicators of fraud, i.e. warning signs, visible from the financial statements of companies in the Republic of Serbia. The aim of the research is to examine whether there are and which are the most common indicators of fraud in financial statements by the practical application of the Beneish model, as one of the most important models for detecting fraud indicators. The research aims to point out that it is possible to reduce the frequency and negative consequences of frauds by preventive analysis of warning signs (fraud indicators). Since the Republic of Serbia is a country with a relatively high bankruptcy rate (Mizdraković \& Bokić, 2016, p. 1368) and since the mentioned financial scandals indicate that companies threatened with bankruptcy are prone to fraudulent financial reporting, it is very important to investigate fraud indicators in the financial statements of companies in the Republic of Serbia.

\section{THE FINANCIAL REPORTING ENVIRONMENT IN THE REPUBLIC OF SERBIA}

According to the report of the Center for Reporting Reform of the World Bank on June 2015, the quality of accounting personnel in enterprises in the Republic of Serbia varies considerably, resources allocated to the accounting function are generally insufficient, and the quality of internal controls is not at a satisfactory level. The same report suggests that smaller businesses run by owners manipulate financial statements to meet creditors' criteria, reduce taxes, or achieve other goals which are incompatible with reliable reporting and that companies try to lower the cost of accounting function by sacrificing the quality of reporting. The general conclusion in the report is that the quality of financial reporting in the Republic of Serbia is not at a satisfactory level (Centre for Financial Reporting Reform, 2015, p. vii). 
Lack of awareness of the importance of financial reporting and insufficient public accountability are key factors that jeopardize the quality of financial reporting in the Republic of Serbia (Đukić \& Pavlović, 2014, p. 111). Due to underdevelopment of capital market, insufficient investment in personnel development, underdevelopment of ownership relations, marginalization of accountants and financial analysts and lack or nonimplementation of adequate legal solutions, many companies are not sufficiently motivated and/or able to present a realistic view of the financial position, profitability and cash flow in financial statements. In other words, the quality of financial reporting is not on the list of companies' priorities in the Republic of Serbia (Stojanović \& Dimitrijević, 2015, p. 7).

Empirical studies (Jakšić, 2010; Mijić, Spahić \& Vuković, 2011; Obradović \& Karapavlović, 2014, 2016, 2016a, 2016c) indicate that companies in the Republic of Serbia which are legally obligated to apply International Financial Reporting Standards (IFRS) are not always fully motivated nor forced to comply with those standards, while auditors do not always react to non-compliance with the standards. Although irregularities in financial reporting cannot be equated with fraud (fraud involves intent, while irregularities can also occur unintentionally, e.g. due to ignorance or negligence), they are, without a doubt, a sign of danger that must not be ignored.

\section{THE APPROACHES TO IDENTIFY FRAUD INDICATORS IN FINANCIAL STATEMENTS}

In the process of investigating fraud in financial reporting, the deductive or inductive approach can be applied (Stančić \& Dimitrijević, 2014, p. 2). The deductive approach, as fairly simple and economical, starts from general analysis and is directed to specific details. It is applied in situations where there are no clear signs of manipulation in relation to specific financial statements positions. Therefore, it is used for preventive investigation or when there is suspicion but no clear signs indicating the area of manipulation. The deductive approach can be based on a variety of techniques, such as relationship analysis, Beneish's analysis, Benford's law, Altman models, BEX model, FEFQM model and general forensic analysis program (Stančić, Dimitrijević \& Stančić, 2013, p. 17). Inductive approach is based on specific experiences regarding financial statements positions. Therefore, these positions are first investigated. This approach is applied when there are significant doubts and warning signs of manipulation regarding certain items of financial statements (Dimitrijević, 2012, p. 22).

Fraud indicators, i.e. warning signs, in financial statements can be defined as important symptoms that indicate that there is a possibility of a fraud in financial statements, i.e. that the statements are fraudulent (deliberately made incorrect). When we notice them, we should not draw 
the conclusion that a fraud has been committed, but only that we should conduct a deeper investigation in order to finally confirm or deny the fraud. The warning signs naturally lead to the creation of effective methods and processes for fraud detection, while such methods, further, lead to the creation of good controls. Accountants and auditors have to be well-trained to identify warning signs and develop a risk model for preventing and detecting fraud. If we timely response to warning signs, the consequences of frauds can be reduced.

Different symptoms could indicate a fraud in financial reporting. Key symptoms of a fraud in financial reporting, which could also indicate fraud of another type (misappropriation of assets or corruption) are accounting anomalies, weaknesses in the internal control system, analytical anomalies, behavioral and lifestyle anomalies of responsible persons, and complaints and denunciations. Accounting anomalies refer to the irregular documentation and incorrect data entries into accounting books. The risk of fraud is greater when internal controls are weak or do not exist or when they can be easily avoided. The weaknesses in the internal controls are reflected, among other things, in inadequate segregation of duties, weak physical protection of assets, and a lack of independent checkouts. Analytical anomalies refer to procedures or transactions occurring at an unusual time or in an unusual place, including persons who have not previously been involved, in which unusually high or low amounts occur and which occur very often or rarely (Dimitrijević, 2012, p. 8). An unusual decrease in assets, deviations from specifications, increased inventory write-off, increased volume of purchases, unrealistically high costs, significant changes in ratios, and unusual relationships of financial indicators are examples of analytical anomalies. A fraud could be indicated by numerous anomalies in behavior and lifestyle of responsible persons (persons who are in a position to commit fraud), such as avoidance of a direct view, increased toughness, work biography with multiple interruptions, problematic character, constant anger, tendencies to blame others (Lux \& Fitiani, 2002, pp. 50-51), and attempts to hide information (Singleton \& Singleton, 2010, p. 140). Vuković, Riznić and Voza (2015, p. 329) point out that greed is becoming increasingly evident in business. However, in the context of investigating financial reporting fraud, it is particularly important to find out and investigate problematic or unusual relationships of auditors and managers (International Auditing and Assurance Standards Board, 2016, p. 209). Complaints and denunciations, public or anonymous, addressed to authoritative bodies or individuals in the company or judicial institutions, should be treated with a caution because they are often incorrect or false (Albrecht, Albrecht, Albrecht \& Zimbelman, 2009 , p. 134). The research in this paper is based on the perception of analytical anomalies. 


\section{RESEARCH METHODOLOGY AND SAMPLE}

Widely recognized and applied Beneish model as a mathematical model used to estimate the probability that a company manipulated its accounting books and, consequently, its financial statements is used as a methodological basis for empirical research in this paper. The model is based on the indexes that measure changes in general ledger accounts balances, i.e. changes in financial statements positions, in comparison to the previous year (Kass-Shraibman \& Sampath, 2011, p. 81). The model was derived from the survey conducted by Messod D. Beneish, professor of the Indiana University (USA), from 1982 to 1992. The survey was based on a comparison of financial statements of (a) companies in the USA which, according to the previous knowledge, had prepared fraudulent financial statements (manipulators), and (b) companies in the USA for which manipulations had not been detected (non-manipulators). In particular, eight variables determined on the basis of data presented in balance sheets and profit and loss statements of the observed companies were the subjects of comparison, i.e. (Beneish, 1999, pp. 26-28):

1. days' sales in receivables index (DSRI):

$$
\begin{aligned}
& \frac{\text { receivables }_{t} / \text { sales }_{t}}{\text { receivables }_{t-1} / \text { sales }_{t-1}} \\
& \text { ( } \mathrm{t} \text { - current year; } \mathrm{t}-1 \text { - previous year); }
\end{aligned}
$$

2. gross margin index (GMI):

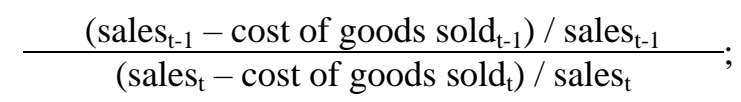

3. asset quality index (AQI):

$1-\left(\right.$ current assets $_{\mathrm{t}}+$ net PP\&E $\left.\mathrm{E}_{\mathrm{t}}\right) /$ total $^{\text {assets }} \mathrm{t}_{\mathrm{t}}$

$1-\left(\right.$ current $^{\text {assets }} \mathrm{t}_{\mathrm{t}-1}+$ net PP\&E $\left.\mathrm{E}_{\mathrm{t}-1}\right) /$ total $_{\text {assets }} \mathrm{t}_{\mathrm{t}-1}$

(PP\&E - property, plant and equipment);

4. sales growth index (SGI):

$$
\frac{\text { sales }_{\mathrm{t}}}{\text { sales }_{\mathrm{t}-1}}
$$

5. depreciation index (DEPI):

$$
\frac{\text { depreciation }_{\mathrm{t}-1} /\left(\text { depreciation }_{\mathrm{t}-1}+\text { net } \mathrm{PP} \& \mathrm{E}_{\mathrm{t}-1}\right)}{\text { depreciation }_{\mathrm{t}} /\left({\text { depreciation } P P \& \mathrm{E}_{\mathrm{t}}+\text { net PP\&E}}_{\mathrm{t}}\right)} ;
$$

6. sales, general, and administrative expenses index (SGAI):

sales, general, and administrative expense ${ }_{t} /$ sales $_{t}$

sales, general, and administrative expense $\mathrm{t}_{\mathrm{t}-1} / \mathrm{sales}_{\mathrm{t}-1}$ 


\section{7. leverage index (LVGI):}

(long-term debts + current liabilities $_{\mathrm{t}}$ )/ total assets $\mathrm{t}_{\mathrm{t}}$

(long-term debts $\mathrm{t}_{\mathrm{t}-1}+$ current liabilities $_{\mathrm{t}-1}$ ) / total assets $\mathrm{t}_{\mathrm{t}-1}$

8. total accruals to total assets (TATA):

$\triangle$ current assets $_{\mathrm{t}}-\triangle$ cash $_{\mathrm{t}}-\triangle$ current liabilities $_{\mathrm{t}}$

$-\triangle$ current maturities of long-term debts $\mathrm{t}_{\mathrm{t}} \triangle$ income tax payable $_{\mathrm{t}}$ - depreciation and amortization $_{\mathrm{t}}$

total assets $\mathrm{t}_{\mathrm{t}}$

In explanation of the indexes, Beneish (1999, pp. 26-28) points out that a significant change in receivables could be caused by changes in credit policy aimed at sales increasing. However, a disproportionate increase in receivables in relation to sales could also indicate an overvaluation of sales. Therefore, a significant increase in the ratio of these variables, i.e. DSRI significantly higher than 1, could indicate an overvaluation of sales, and thus profit. The deterioration of GMI is a negative signal of the company's future, wherein it could be expected that companies with worse future prospects are more inclined to manipulations in financial reporting. AQI measures changes in the share of assets with less secure future economic benefits, and its growth could indicate manipulation in the form of unjustified cost capitalization (recognition of assets), thereby delaying expense recognition. An increase in sales, reflected in SGI, does not imply manipulation, but growing companies could be considered as more likely to commit fraud, wherein incentives for fraud arise from their financial position and a need to attract additional capital. DEPI greater than 1 could point to changes in depreciation regime aimed to reduce annual depreciation and thus increase earnings for a period. Increase in share of management, sales and administration expenses in sales revenues, i.e. SGAI greater than 1 , could be considered as a negative signal of the company's perspective. Therefore, it can be expected that companies would be more prone to manipulations as this index is higher than 1. According to Beneish, LVGI is included in consideration to be examined whether the level of leverage is related to motivation for frauds. The index of the share of accrual items in total assets (TATA) reflects the relationship between cash flow and reported earnings. Beneish uses the change in net working capital, excluding cash, less depreciation and amortization as an approximation of accrual items, as items related to the application of accrual basis of accounting, i.e. with recognition of income and expenses before or after cash inflows or outflows, expecting that higher share of non-cash items is associated with higher risk of manipulation. The next way to calculate this index can also be found in the literature (Mehta \& Bhavani, 2017, p. 698): 
$\frac{\text { income from continuing operations } \mathrm{s}_{\mathrm{t}}-\text { cash flow from operating activities } \mathrm{s}_{\mathrm{t}}}{\text { total assets }_{\mathrm{t}}}$.

The Beneish's research results, shown in Table 1, reveals that changes in relations of certain positions are more pronounced in the case of companies that manipulate financial statements than in the case of companies that do not manipulate. For example, the average DSRI is 1.465 for manipulators and 1.031 for non-manipulators. Statistically significant differences in the average values between manipulators and nonmanipulators were found for five variables (DSRI, GMI, AQI, SGI and TATA), but not for the rest three variables (DEPI, SGAI and LVGI).

Table 1 The Beneish's research results

\begin{tabular}{lcc}
\hline \multicolumn{1}{c}{ Variable } & $\mathrm{M}$ & $\mathrm{N}$ \\
\hline 1. days' sales in receivables index (DSRI) & 1.465 & 1.031 \\
2. gross margin index (GMI) & 1.193 & 1.014 \\
3. asset quality index (AQI) & 1.254 & 1.039 \\
4. sales growth index (SGI) & 1.607 & 1.134 \\
5. depreciation index (DEPI) & 1.077 & 1.001 \\
6. sales, general, and administrative expenses index (SGAI) & 1.041 & 1.054 \\
7. leverage index (LVGI) & 1.111 & 1.037 \\
8. total accruals to total assets (TATA) & 0.031 & 0.018 \\
\hline \multicolumn{3}{c}{ M-average for manipulators, N-average for non-manipulators } \\
\multicolumn{2}{c}{ Source: Beneish, 1999, 24-28. }
\end{tabular}

Beneish further developed the next model for calculating the unique indicator of fraud risk: M8 $=-4.84+0.92 \mathrm{DSRI}+0.528 \mathrm{GMI}+$ $0.404 \mathrm{AQI}+0.892 \mathrm{SGI}+0.115 \mathrm{DEPI}-0.172 \mathrm{SGAI}+4.679 \mathrm{TATA}-$ $0.327 \mathrm{LVGI}$. The limit value in the model is -2.22 . The value above the limit means that there are indications of fraud in financial reporting. In the literature, the next version of the model, with five variables and the same limit value, can also be found: M5 $=-6.065+0.823$ DSRI + $0.906 \mathrm{GMI}+0.593 \mathrm{AQI}+0.717 \mathrm{SGI}+0.107 \mathrm{DEPI}$ (Mehta \& Bhavani, 2017, p. 698).

One of the key constraints of the Beneish model is that it was created on the basis of financial statements prepared in accordance with the U.S. generally accepted accounting principles (GAAP). If the Beneish's research included financial statements prepared in accordance with some other basis of financial reporting, the results might have been different, i.e. the model might have a different form. Therefore, we should be particularly cautious when making conclusions in situations where financial statements based on standards other than the U.S. GAAP (e.g. IFRS) are analyzed. Also, if the same company prepared fraudulent financial statements for a number of consecutive years, the Beneish model will not be enough reliable. This model, in essence, detects changes in 
financial statements, but cannot fully illuminate causes of the changes. It can indicate a fraud when the fraud does not exist. The changes detected by the model can be completely legal. Therefore, the Beneish model can be used only as a mean for identification of financial reporting areas requiring additional research (Stančić \& Dimitrijević, 2014, pp. 496-497).

The Beneish model has been widely tested in practice, both inside and outside the USA. In the literature, there are numerous examples of testing financial statements of companies with this model. It is particularly interesting that the model proved to be adequate in the case of "Enron". The studies show that the signs of fraud could be timely saw if the financial statements of the mentioned company for the years preceding the bankruptcy were tested (see: Mavengere, 2015; Mehta \& Bhavani, 2017).

The research in this paper is conducted on a sample of 42 business entities of different size and activity, on the basis of their financial statements for 2013 and 2014, available on the website of the Serbian Business Registers Agency. The research is conducted to reveal: (a) the extent of fraud risk in financial reporting in the Republic of Serbia; (b) which categories of business entities are related to the highest fraud risk; and (c) which warning signs are the most common. Table 2 shows the sample structure. We use both of the mentioned model variants (M8 and M5), while the interpretation of the results is based on (a) the values in Table 1 (in the cases of individual indexes) and (b) the limit value of 2.22 (in the cases of M8 and M5).

Table 2 Sample structure

\begin{tabular}{lcc}
\hline & Number & Percentage share \\
\hline Size & & \\
$\quad$ small and middle-sized company & 11 & 26.2 \\
large company & 31 & 73.8 \\
Legal form & & \\
$\quad$ limited liability company & 25 & 59.5 \\
stock company & 17 & 40.5 \\
Primary activity & & \\
manufacturing & 11 & 26.2 \\
trade & 10 & 23.8 \\
services & 11 & 26.2 \\
finance & 10 & 23.8 \\
\hline
\end{tabular}

Source: author's calculation

Given that financial statements prepared on the basis of IFRS are analyzed, it is clear that the aforementioned model limitations come to the fore. In addition, it is important to point out that the calculation of indexes that make up the Beneish model requires some adjustments and approximations. Namely, the templates of financial statements used by companies in the Republic of Serbia are designed so that some of the 
model variables are not available. This is especially true for the income statement template, in which expenses are presented by nature, while Beneish model requires the presentation by function. We use costs of material used as a replacement for the missing costs of goods sold, and salaries, salaries compensations, and other personal expenses as a replacement for the missing sales, general and administration expenses. GMI is not computed for financial institutions because of the specificities in the structures of their revenues and expenses. Given the constraints of the model itself and the modifications made, it is clear that the results can only have the character of indications. Nevertheless, indications may also be useful in the context of the effort to perceive the effectiveness of the current mechanisms for financial reporting control.

\section{RESEARCH RESULTS}

Table 3 shows the results of the descriptive statistical analysis. The average value of the DSRI indicator at the sample level, in both observed years, is between the average value for manipulators (column $\mathrm{M}$ in Table 1) and the average value for non-manipulators (column $\mathrm{N}$ in Table 1) in the Beneish's research. This indicates generally moderate fraud risk related to revenue recognition in the Republic of Serbia. GMI is very close to one in both observed years and indicates a low fraud risk. The average values of SGI and TATA, which are close to the average values for non-manipulators in the Beneish's research, lead to a similar conclusion. AQI indicates a low risk of unjustified costs capitalization. DEPI and SGAI for 2013 are almost equal to one indicating a very low risk of manipulation. However, the same indicators for 2014 are notably higher indicating a high risk. By contrast, the average LVGI for 2013 is very high, while the same indicator for 2014 drops sharply, although it remains at a level that indicates a significant risk of manipulation. In any case, the borrowing activities of companies are a significant threat to the faithful presentation of financial statements. Summarized indicators (M8 and M5) for both observed years indicate a low general risk of manipulation. Wilcoxon's rank test reveals that only in the case of LVGI the difference between the observed years is statistically significant with a medium effect size $(\mathrm{Z}=-2.757 ; \mathrm{p}=0.006 ; \mathrm{r}=0.301)$. 
Table 3 Descriptive statistical analysis

\begin{tabular}{lrrcrrr}
\hline Variable & $\mathrm{n}$ & mean & $\begin{array}{c}\text { standard } \\
\text { deviation }\end{array}$ & median & minimum & maximum \\
\hline DSRI (2014) & 42 & 1.123 & 0.503 & 1.045 & 0.444 & 3.677 \\
DSRI (2013) & 42 & 1.126 & 0.409 & 1.056 & 0.550 & 2.578 \\
GMI (2014) & 32 & 1.005 & 0.088 & 1.001 & 0.756 & 1.288 \\
GMI (2013) & 32 & 0.994 & 0.047 & 1.006 & 0.887 & 1.072 \\
AQI (2014) & 41 & 1.075 & 0.894 & 0.913 & 0.058 & 5.699 \\
AQI (2013) & 41 & 1.035 & 0.604 & 1.020 & 0.039 & 3.275 \\
SGI (2014) & 42 & 1.126 & 0.781 & 1.044 & 0.138 & 5.855 \\
SGI (2013) & 42 & 1.140 & 0.788 & 1.027 & 0.657 & 6.000 \\
TATA (2014) & 42 & -0.027 & 0.606 & -0.030 & -3.312 & 0.962 \\
TATA (2013) & 42 & 0.004 & 0.485 & -0.001 & -2.337 & 0.961 \\
DEPI (2014) & 42 & 1.101 & 0.337 & 1.042 & 0.748 & 2.417 \\
DEPI (2013) & 42 & 0.998 & 0.296 & 1.023 & 0.001 & 1.876 \\
SGAI (2014) & 42 & 1.109 & 0.722 & 0.997 & 0.221 & 4.944 \\
SGAI (2013) & 42 & 1.016 & 0.257 & 1.059 & 0.090 & 1.714 \\
LVGI (2014) & 42 & 1.121 & 0.479 & 1.014 & 0.258 & 3.040 \\
LVGI (2013) & 42 & 1.866 & 2.276 & 1.142 & 0.521 & 14.787 \\
M8 (2014) & 42 & -2.529 & 2.881 & -2.443 & -18.186 & 1.769 \\
M8 (2013) & 42 & -2.630 & 2.535 & -2.469 & -14.548 & 1.714 \\
M5 (2014) & 42 & -2.903 & 0.752 & -2.899 & -4.121 & -0.928 \\
M5 (2013) & 42 & -2.931 & 0.703 & -2.911 & -4.290 & -0.038 \\
\hline
\end{tabular}

Source: author's calculation

In addition to the average values of indicators, individual values are also important, especially those that point to a high risk of fraud in financial reporting. Table 4 contains the distribution of fraud risk based on individual variables, whereby the values above those in column $\mathrm{M}$ of Table 1 indicate a high risk of fraud, the values between those in columns $\mathrm{M}$ and $\mathrm{N}$ indicate a moderate risk, and the values below those in column $\mathrm{N}$ indicate a low risk. Although Beneish did not reveal statistical significance in the cases of DEPI and LVGI, the values in Table 1, as sufficiently distinctive, are used to assess fraud risk. In the case of SGAI, where the Beneish's average values for manipulators and non-manipulators are very close, we assume that the risk is high risk if the value is above 1.050 and that the risk is moderate if it is between 1.000 and 1.050. In assessing the degree of fraud risk in the described sense, the observations for 2013 and 2014 are considered together. 
Table 4 Fraud risk based on individual variables

\begin{tabular}{|c|c|c|c|}
\hline Variable & low risk & moderate risk & high risk \\
\hline \multicolumn{4}{|l|}{ DSRI } \\
\hline whole sample & $39(46 \%)$ & $35(42 \%)$ & $10(12 \%)$ \\
\hline small and medium-sized entities & $9(41 \%)$ & $11(50 \%)$ & $2(9 \%)$ \\
\hline large entities & $30(48 \%)$ & $24(39 \%)$ & $8(13 \%)$ \\
\hline stock companies & $18(53 \%)$ & $12(35 \%)$ & $4(12 \%)$ \\
\hline limited liability companies & $21(42 \%)$ & $23(46 \%)$ & $6(12 \%)$ \\
\hline manufacturing companies & $9(41 \%)$ & $10(45 \%)$ & $3(14 \%)$ \\
\hline trade companies & $7(35 \%)$ & $8(40 \%)$ & $5(25 \%)$ \\
\hline service companies & $12(55 \%)$ & $9(41 \%)$ & $1(5 \%)$ \\
\hline financial institutions & $11(55 \%)$ & $8(40 \%)$ & $1(5 \%)$ \\
\hline \multicolumn{4}{|l|}{ GMI } \\
\hline whole sample & $41(64 \%)$ & $22(34 \%)$ & $1 \quad(2 \%)$ \\
\hline small and medium-sized entities & $11(55 \%)$ & $9(45 \%)$ & $0 \quad(0 \%)$ \\
\hline large entities & $30(68 \%)$ & $13(30 \%)$ & $1(2 \%)$ \\
\hline stock companies & $11(69 \%)$ & $5(31 \%)$ & $0 \quad(0 \%)$ \\
\hline limited liability companies & $30(63 \%)$ & $17(35 \%)$ & $1(2 \%)$ \\
\hline manufacturing companies & $12(55 \%)$ & $9(41 \%)$ & $1(5 \%)$ \\
\hline trade companies & $11(55 \%)$ & $9(45 \%)$ & $0 \quad(0 \%)$ \\
\hline service companies & $18(82 \%)$ & $4(18 \%)$ & $0 \quad(0 \%)$ \\
\hline financial institutions & - & - & - \\
\hline \multicolumn{4}{|l|}{ AQI } \\
\hline whole sample & $52(63 \%)$ & $18(22 \%)$ & $12(15 \%)$ \\
\hline small and medium-sized entities & $15(75 \%)$ & $4(20 \%)$ & $1(5 \%)$ \\
\hline large entities & $37(60 \%)$ & $14(23 \%)$ & $11(18 \%)$ \\
\hline stock companies & $17(50 \%)$ & $10(29 \%)$ & $7(21 \%)$ \\
\hline limited liability companies & $35(73 \%)$ & $8(17 \%)$ & $5(10 \%)$ \\
\hline manufacturing companies & $13(59 \%)$ & $7(32 \%)$ & $2(9 \%)$ \\
\hline trade companies & $16(80 \%)$ & $2(10 \%)$ & $2(10 \%)$ \\
\hline service companies & $11(50 \%)$ & $6(27 \%)$ & $3(14 \%)$ \\
\hline financial institutions & $12(60 \%)$ & $3(15 \%)$ & $5(25 \%)$ \\
\hline \multicolumn{4}{|l|}{ SGI } \\
\hline whole sample & $69(82 \%)$ & $12(14 \%)$ & $3(4 \%)$ \\
\hline small and medium-sized entities & $19(86 \%)$ & $2(9 \%)$ & $1(5 \%)$ \\
\hline large entities & $50(81 \%)$ & $10(16 \%)$ & $2(3 \%)$ \\
\hline stock companies & $19(79 \%)$ & $3(12 \%)$ & $2(8 \%)$ \\
\hline limited liability companies & $40(80 \%)$ & $9(18 \%)$ & $1(2 \%)$ \\
\hline manufacturing companies & $22(100 \%)$ & $0 \quad(0 \%)$ & $0 \quad(0 \%)$ \\
\hline trade companies & $16(80 \%)$ & $4(20 \%)$ & $0 \quad(0 \%)$ \\
\hline service companies & $16(73 \%)$ & $5(23 \%)$ & $1(5 \%)$ \\
\hline financial institutions & $15(75 \%)$ & $3(15 \%)$ & $2(10 \%)$ \\
\hline
\end{tabular}




\begin{tabular}{|c|c|c|c|}
\hline Variable & low risk & moderate risk & high risk \\
\hline \multicolumn{4}{|l|}{ TATA } \\
\hline whole sample & $45(54 \%)$ & $2(2 \%)$ & $37(44 \%)$ \\
\hline small and medium-sized entities & $9(41 \%)$ & $1(5 \%)$ & $12(55 \%)$ \\
\hline large entities & $36(58 \%)$ & $1(2 \%)$ & $25(40 \%)$ \\
\hline stock companies & $16(47 \%)$ & $0(0 \%)$ & $18(53 \%)$ \\
\hline limited liability companies & $29(58 \%)$ & $2(4 \%)$ & $19(38 \%)$ \\
\hline manufacturing companies & $8(36 \%)$ & $1(5 \%)$ & $13(59 \%)$ \\
\hline trade companies & $18(90 \%)$ & $0(0 \%)$ & $2(2 \%)$ \\
\hline service companies & $15(68 \%)$ & $1(5 \%)$ & $6(27 \%)$ \\
\hline financial institutions & $4(20 \%)$ & $0(0 \%)$ & $16(80 \%)$ \\
\hline \multicolumn{4}{|l|}{ DEPI } \\
\hline whole sample & $32(38 \%)$ & $25(30 \%)$ & $27(32 \%)$ \\
\hline small and medium-sized entities & $5(23 \%)$ & $10(45 \%)$ & $7(32 \%)$ \\
\hline large entities & $27(44 \%)$ & $15(24 \%)$ & $20(32 \%)$ \\
\hline stock companies & $12(35 \%)$ & $10(29 \%)$ & $12(35 \%)$ \\
\hline limited liability companies & $20(40 \%)$ & $15(30 \%)$ & $15(30 \%)$ \\
\hline manufacturing companies & $11(50 \%)$ & $6(27 \%)$ & $5(23 \%)$ \\
\hline trade companies & $9(45 \%)$ & $7(35 \%)$ & $4(20 \%)$ \\
\hline service companies & $5(23 \%)$ & $9(41 \%)$ & $8(36 \%)$ \\
\hline financial institutions & $7(35 \%)$ & $3(15 \%)$ & $10(50 \%)$ \\
\hline \multicolumn{4}{|l|}{ SGAI } \\
\hline whole sample & $37(44 \%)$ & $11(13 \%)$ & $36(43 \%)$ \\
\hline small and medium-sized entities & $10(45 \%)$ & $2(9 \%)$ & $10(45 \%)$ \\
\hline large entities & $27(44 \%)$ & $9(15 \%)$ & $26(42 \%)$ \\
\hline stock companies & $17(50 \%)$ & $4(12 \%)$ & $13(38 \%)$ \\
\hline limited liability companies & $20(40 \%)$ & $7(14 \%)$ & $23(46 \%)$ \\
\hline manufacturing companies & $8(36 \%)$ & $4(18 \%)$ & $10(45 \%)$ \\
\hline trade companies & $5(25 \%)$ & $3(15 \%)$ & $12(60 \%)$ \\
\hline service companies & $11(50 \%)$ & $3(14 \%)$ & $8(36 \%)$ \\
\hline financial institutions & $13(65 \%)$ & $1(5 \%)$ & $6(30 \%)$ \\
\hline \multicolumn{4}{|l|}{ LVGI } \\
\hline whole sample & $37(44 \%)$ & $9(11 \%)$ & $38(45 \%)$ \\
\hline small and medium-sized entities & $7(32 \%)$ & $2(9 \%)$ & $13(59 \%)$ \\
\hline large entities & $30(48 \%)$ & $7(11 \%)$ & $25(40 \%)$ \\
\hline stock companies & $16(47 \%)$ & $4(12 \%)$ & $14(41 \%)$ \\
\hline limited liability companies & $21(42 \%)$ & $5(10 \%)$ & $24(48 \%)$ \\
\hline manufacturing companies & $8(36 \%)$ & $0(0 \%)$ & $14(64 \%)$ \\
\hline trade companies & $11(55 \%)$ & $2(10 \%)$ & $7(35 \%)$ \\
\hline service companies & $8(36 \%)$ & $2(9 \%)$ & $12(55 \%)$ \\
\hline financial institutions & $10(50 \%)$ & $5(25 \%)$ & $5(25 \%)$ \\
\hline \multicolumn{4}{|l|}{ Summary } \\
\hline whole sample & $352(54 \%)$ & $134(21 \%)$ & $164(25 \%)$ \\
\hline small and medium-sized entities & $85(49 \%)$ & $41(24 \%)$ & $46(27 \%)$ \\
\hline large entities & $267(56 \%)$ & $93(19 \%)$ & $118(25 \%)$ \\
\hline stock companies & $136(54 \%)$ & $48(19 \%)$ & $70(28 \%)$ \\
\hline limited liability companies & $216(55 \%)$ & $86(22 \%)$ & $94(24 \%)$ \\
\hline manufacturing companies & $91(52 \%)$ & $37(21 \%)$ & $48(27 \%)$ \\
\hline trade companies & $93(58 \%)$ & $35(22 \%)$ & $32(20 \%)$ \\
\hline service companies & $96(55 \%)$ & $39(22 \%)$ & $39(22 \%)$ \\
\hline financial institutions & $72(51 \%)$ & $23(16 \%)$ & $45(32 \%)$ \\
\hline
\end{tabular}

Source: author's calculation 
Table 4 confirms that a high fraud risk is related to borrowing activities of companies (especially manufacturing companies). Although the average values of TATA, DEPI and SGAI do not indicate a high risk, the situation is different when considering individual values. A significant number of observations shows a high risk of manipulation with accrual items in general (TATA) and depreciation in particular (DEPI). A high risk of fraud is associated with an increase in the share of administrative costs in a significant number of cases. Analyses based on GMI and SGI, again, reveal a low risk. The summarized data in Table 4 shows that a high risk is detected in one-quarter of the observations and that the risk is moderate in one-fifth of the observations, wherein the share of observations that indicate a high risk is higher for manufacturing companies and financial institutions than for trade and service companies. According to the results of analysis based on the variables M5 and M8, shown in Table 5, the limit value of -2.22 is exceeded in $28 \%$ of the observations, which means there is an indication of fraud. The analysis reveals a higher risk for financial institutions and manufacturing companies. The difference in the number of risky observations between M5 and M8 can be explained by the fact that M5 does not include the risk of manipulation with accruals (i.e. TATA index), which is identified as significant for companies in the Republic of Serbia.

Mann-Whitney $U$ test is conducted to determine whether there are significant differences between the levels of fraud risk in financial reporting for companies of different size. The test reveals statistical significance, with a medium effect size, in differences between large companies, on the one hand, and small and medium-sized companies, on the other hand, in the cases of AQI for $2013(\mathrm{U}=82 ; \mathrm{z}=-2,216 ; \mathrm{p}=0.026 ; \mathrm{r}=0.346)$ and SGI for the same year $(U=87 ; z=-2.389 ; p=0.016 ; r=0.368)$. The median of AQI for 2013 is 1.066 for large companies and 0.801 for small and medium-sized companies, so it can be concluded that fraud risk related to cost capitalization is higher for large companies. The median for SGI for 2013 is 1.036 for large companies and 0.896 for small and medium-sized companies, which means that fraud risk associated with growth in sales is, again, higher for large companies.

The same test is used to determine whether there are significant differences between the levels of fraud risk in companies of different legal form. The test reveals statistical significance only for AQI for 2013, with a medium size effect $(\mathrm{U}=98 ; \mathrm{z}=-2.805 ; \mathrm{p}=0.005 ; \mathrm{r}=0.438)$. The median for this variable is 1.082 for stock companies and 0.913 for limited liability companies, so it can be concluded that the risk of fraud related to cost capitalization is higher for stock companies. 
Table 5 Fraud risk based on the summarizing variables

\begin{tabular}{lrr}
\hline Variable & $\begin{array}{c}\text { The number of } \\
\text { observations } \\
\text { Above }-2,22\end{array}$ & $\begin{array}{r}\text { The number of } \\
\text { observations } \\
\text { Below }-2,22\end{array}$ \\
\hline M8 & $38(45 \%)$ & $46(55 \%)$ \\
whole sample & $10(45 \%)$ & $12(55 \%)$ \\
\hline small and medium-sized entities & $28(45 \%)$ & $34(55 \%)$ \\
large entities & $17(50 \%)$ & $17(50 \%)$ \\
stock companies & $21(42 \%)$ & $29(58 \%)$ \\
limited liability companies & $11(50 \%)$ & $11(50 \%)$ \\
manufacturing companies & $4(20 \%)$ & $16(80 \%)$ \\
trade companies & $7(32 \%)$ & $15(68 \%)$ \\
service companies & $16(80 \%)$ & $4(20 \%)$ \\
financial institutions & & \\
\hline M5 & $9(11 \%)$ & $75(89 \%)$ \\
whole sample & $0(0 \%)$ & $22(100 \%)$ \\
\hline small and medium-sized entities & $9(15 \%)$ & $53(85 \%)$ \\
large entities & $4(12 \%)$ & $30(88 \%)$ \\
stock companies & $5(10 \%)$ & $45(90 \%)$ \\
limited liability companies & $3(14 \%)$ & $19(86 \%)$ \\
manufacturing companies & $3(15 \%)$ & $17(85 \%)$ \\
trade companies & $0(0 \%)$ & $22(100 \%)$ \\
service companies & $3(15 \%)$ & $17(85 \%)$ \\
financial institutions & $77(28 \%)$ & $121(72 \%)$ \\
\hline Summary & $10(34 \%)$ & $34(77 \%)$ \\
whole sample & $37(30 \%)$ & $87(70 \%)$ \\
\hline small and medium-sized entities & $21(31 \%)$ & $47(69 \%)$ \\
large entities & $26(26 \%)$ & $74(74 \%)$ \\
stock companies & $14(32 \%)$ & $30(68 \%)$ \\
limited liability companies & $7(18 \%)$ & $33(83 \%)$ \\
manufacturing companies & $37(84 \%)$ \\
trade companies & $21(53 \%)$ \\
service companies & $19(48 \%)$ & \\
financial institutions & & \\
& & \\
& & \\
\hline
\end{tabular}

Source: author's calculation

Kruskal-Wallis test is conducted to determine if there are significant differences between the levels of fraud risk in companies of different activity. Table 6 shows the results of this test for variables in which statistical significance is revealed, along with the order of medians.

The results in Table 6 reveal that fraud risk related to sales revenues is the greatest for trade companies and that fraud risk related to accrual items is the greatest for financial institutions. While the analysis of the M8 indicator reveals the highest risk for financial institutions, the analysis of the M5 indicator reveals that the risk for these entities is the lowest. This finding, again, indicates the significance of fraud risk in 
relation to accrual items in the case of financial institutions. Namely, the risk profile changes significantly when TATA is excluded from the model.

Table 6 Fraud risk in companies of different activity

\begin{tabular}{|c|c|c|c|c|c|}
\hline \multirow[t]{2}{*}{ Variable } & \multirow[t]{2}{*}{ Kruskal-Wallis test } & \multicolumn{4}{|c|}{$\begin{array}{c}\text { Order of medians } \\
\text { (1-the highest; } 4 \text { - the lowest) }\end{array}$} \\
\hline & & 1 & 2 & 3 & 4 \\
\hline DSRI (2014) & $\chi^{2}(3, n=42)=10.454 ; p=0.015$ & $\mathrm{~T}$ & $\mathrm{M}$ & $\mathrm{S}$ & $\mathrm{F}$ \\
\hline TATA (2014) & $\chi^{2}(3, n=42)=14.798 ; p=0.002$ & $\mathrm{~F}$ & M & S & $\mathrm{T}$ \\
\hline TATA (2013) & $\chi^{2}(3, n=42)=10.189 ; p=0.017$ & $\mathrm{~F}$ & M & S & $\mathrm{T}$ \\
\hline M8 (2014) & $\chi^{2}(3, n=42)=9.687 ; p=0.021$ & $\mathrm{~F}$ & M & $\mathrm{T}$ & $\mathrm{S}$ \\
\hline M8 (2013) & $\chi^{2}(3, n=42)=9.987 ; p=0.019$ & $\mathrm{~F}$ & M & $\mathrm{T}$ & S \\
\hline M5 (2014) & $\chi^{2}(3, n=42)=8.237 ; p=0.041$ & $\mathrm{~T}$ & $S$ & M & $\mathrm{F}$ \\
\hline M5 (2013) & $\chi^{2}(3, n=42)=8.596 ; p=0.035$ & M & $\mathrm{T}$ & S & $\mathrm{F}$ \\
\hline
\end{tabular}

\section{CONCLUSIONS}

The research in the paper, based on Beneish model, reveals a number of signs of fraud in financial statements of companies in the Republic of Serbia. Given the purpose and limitations of the model applied, the research results should be considered as indications, not as irrefutable facts. Only after concrete and direct forensic examinations of the operations of individual companies, which go beyond the scope of this research, it could be ascertained whether and to what extent companies really prepare fraudulent financial statements.

The research suggests that, generally speaking, there is a moderate risk of fraud in financial statements. This risk is, to a significant extent, related to borrowing activities of companies. In addition, the general risk of manipulation in revenue recognition is identified. A high risk of manipulation with accrual items in general and depreciation in particular is identified for a significant number of companies, despite the fact that the overall risk is not at a high level in these financial reporting areas. Increased share of administrative costs also indicates a high risk in a significant number of cases. Fraud risk is higher for manufacturing companies and financial institutions than for trade and service companies. However, a part of the previous statement relating to financial institutions should be taken with a special reservation, as the limitations of Beneish model are particularly evident in this type of entity. Fraud risk related to cost capitalization and increase in sales are higher for large than for small and medium-sized companies. Fraud risk related to cost capitalization is higher for stock companies than for limited liability companies. The 8variable model is more proper than the 5-variable model for examining 
the financial statements in the Republic of Serbia because the 5-variable model does not take into account a risk related to manipulation with accrual items, which is not insignificant.

The research results indicate that the existing levels of financial reporting quality control in the Republic of Serbia, which primarily include internal and external auditing, are not able enough to prevent fraud due to limitations that are immanent to them. Consequently, there is a need for additional levels of control. Forensic accountants with a legal authority to investigate in more detail every suspicion of fraud (not only in financial reporting but also in business in general) could be the holders of such a control. In order to prevent and detect fraud in financial reporting and, in general, in order to enhance financial reporting quality, it is necessary to regulate the powers and responsibilities of fraud investigators by a separate law. Also, the government should cooperate with professional organizations and educational institutions in the field of educating accountants and developing new professions.

\section{REFERENCES}

Albrecht, W.S., Albrecht, C.C., Albrecht, C.O., \& Zimbelman, M. (2009). Fraud Examination. Mason: South-Western Cengage Learning.

Association of Certified Fraud Examiners (2016). Report to the Nations on Occupational Fraud and Abuse: 2016 Global Fraud Study.

Beneish, M.D. (1999). The Detection of Earnings Manipulation. Financial Analysts Journal, 55, 5, 24-36.

Centre for Financial Reporting Reform (2015). Republic of Serbia - Report on Observance of Standards and Codes on Accounting and Auditing: Update. Vienna: World Bank.

Dimitrijević, D. (2012). Metode i instrumenti forenzičkog računovodstva za otkrivanje prevara u finansijskim izveštajima [Forensic accounting methods and instruments for detecting fraud in financial statements]. Računovodstvo, 56, 3-4, 17-24.

Đukić, T., \& Pavlović, M. (2014), Kvalitet finansijskog izveštavanja u Republici Srbiji [The Quality of Financial Reporting in the Republic of Serbia]. Ekonomske teme, 52, 1, 101-116, doi: 10.1515/ethemes-2014-0007.

International Auditing and Assurance Standards Board (2016) Handbook of International Quality Control, Auditing, Review, Other Assurance, and Related Services Pronouncements. 2016-2017 Edition, Volume 1. New York: IFAC.

Jakšić, D. (2010). Regulativa i praksa obelodanjivanja povezanih strana u finansijskim izveštajima $\mathrm{u}$ Republici Srbiji [Regulation and practice of related party disclosure in the financial statements in the Republic of Serbia]. In J. Čanak, J. (Ed.), Mogućnosti i ograničenja razvoja računovodstvene profesije u Srbiji [Possibilities and limitations of the accounting profession development in Serbia] (pp. 96-109), Zlatibor: Savez računovođa i revizora Srbije.

Kass-Shraibman, F., \& Sampath, V.S. (2011). Forensic Accounting for Dummies. Hoboken: Wiley Publishing, Inc.

Lux, A.G., \& Fitiani, S. (2002). Fighting Internal Crime Before It Happens. Information Systems Control Journal, 3, 50-51. 
Mavengere, K. (2015). Predicting corporate bankruptcy and earnings manipulation using the Altman Z-score and Beneish $\mathrm{M}$ score: The case of $\mathrm{Z}$ manufacturing firm in Zimbabwe. International Journal of Management Sciences and Business Research, 4, 10, 8-14.

Mehta, A., \& Bhavani, G. (2017), Application of Forensic Tools to Detect Fraud: The Case of Toshiba. Journal of Forensic and Investigative Accounting, 9, 1, 692-710.

Mijić, K., Spahić, N., \& Vuković, B. (2011). Regulativa i praksa finansijskog izveštavanja o biološkim sredstvima u Republici Srbiji [Regulation and Practice of the Financial Reporting of Biological Assets in Republic of Serbia]. Ekonomika poljoprivrede, 58, 4, 647-659.

Mizdraković, V. \& Bokić, M. (2016). Ponovna procena prognostičke moći modela za predviđanje stečaja u Republici Srbiji [Reassessment of Corporate Bankruptcy Prediction Models Efficiency: Evidence From Serbia]. Teme, 40, 4, 1367-1382.

Needles, B.E. Jr., Powers, M. (2007). Financial Accounting. Boston: Houghton Mifflin Company.

Obradović, V., \& Karapavlović, N. (2014). Finansijsko izveštavanje o nekretninama, postrojenjima i opremi u Srbiji [Financial Reporting on Property, Plant and Equipment in Serbia]. Računovodstvo, 58, 11-12, 38-50.

Obradović, V., \& Karapavlović, N. (2016). Eksterno izveštavanje po segmentima u Republici Srbiji [External Segment Reporting in the Republic of Serbia], Ekonomske teme, 54, 1, 155-176, doi: 10.1515/ethemes-2016-0008.

Obradović, V., \& Karapavlović, N. (2016a). Finansijsko izveštavanje o zalihama u Republici Srbiji [Inventory Financial Reporting in the Republic of Serbia]. Računovodstvo, 60, 2, 47-65.

Obradović, V., \& Karapavlović, N. (2016b). Kvalitetno finansijsko izveštavanje kao faktor unapređenja konkurentnosti privrede Republike Srbije [Quality Financial Reporting as a Factor of Improving the Competitiveness of the Economy of the Republic of Serbia]. In V. Marinković, V. Janjić, \& V. Mićić, V. (Eds.), Unapređenje konkurentnosti privrede Republike Srbije [Improving the Competitiveness of the Economy of the Republic of Serbia] (pp. 391-402). Kragujevac: Univerzitet u Kragujevcu - Ekonomski fakultet.

Obradović, V., \& Karapavlović, N. (2016c). The influence of company legal form and size on accounting policies disclosures. In V. Stojanović Aleksić (Ed.), Contemporary Issues in Economics, Business and Management - EBM 2016 (pp. 223-231). Kragujevac: University of Kragujevac - Faculty of Economics.

Singleton, T., \& Singleton, A. (2010). Revizija kriminalne radnje $i$ forenzičko računovodstvo [Fraud Auditing and Forensic Accounting]. Beograd: Savez računovođa i revizora Srbije.

Stančić, P., \& Dimitrijević, D. (2014). Analytical methods analysis in forensic accounting. In G. Radosavljević (Ed.), Contemporary Issues in Economics, Business and Management - EBM 2014 (pp. 485-505). Kragujevac: University of Kragujevac - Faculty of Economics.

Stančić P., Dimitrijević D., \& Stančić V. (2013). Forenzičko računovodstvo odgovor profesije na prevare $u$ finansijskim izveštajima [Forensic Accounting - The Response of the Profession to Financial Statement Frauds]. Teme, 37, 4, 1879-1897.

Stojanović, D., \& Dimitrijević, D. (2015). Uloga i značaj forenzičkog računovodstva u Srbiji u procesu pristupanja Evropskoj uniji [The Role and Importance of Forensic Accounting in Serbia in the Process of Accession to the European Union]. In M. Jakšić, V. Stojanović Aleksić, \& P. Mimović (Eds.), Ekonomsko-socijalni aspekti priključivanja Srbije Evropskoj uniji [Economic 
and Social Aspects of Serbia's Accession to the European Union] (pp. 371381). Kragujevac: Univerzitet u Kragujevcu - Ekonomski fakultet.

Stojilković, M. (2016). Nova računovodstvena direktiva u funkciji unapređivanja finansijskog izveštavanja u Evropskoj uniji [New Accounting Directive with the Aim to Improve Financial Reporting in the European Union]. Teme, 40, 1, 103-122.

Vuković, M., Riznić, D., \& Voza, D. (2015). Etika vrline i njen značaj u računovodstvu [Virtue Ethics and its Importance in Accounting]. Teme, 39, 2, 327-344.

Weireich, T.R., Pearson, T.C., \& Churyk, N.T. (2010). Accounting \& Auditing Research: Tools \& Strategies. Danvers: John Wiley \& Sons, Inc.

\title{
ПОКАЗАТЕЉИ ПРЕВАРА У ФИНАНСИЈСКОМ ИЗВЕШТАВАЊУ У РЕПУБЛИЦИ СРБИЈИ
}

\author{
Драгомир Димитријевић ${ }^{1}$, Владимир Обрадовић $^{1}$, Сунчица Милутиновић $^{2}$ \\ ${ }^{1}$ Универзитет у Крагујевцу, Економски факултет, Крагујевац, Србија \\ ${ }^{2}$ Универзитет у Новом Саду, Економски факултет у Суботици, Суботица, Србија
}

Резиме

Састављање лажних финансијских извештаја један је од облика превара у пословању и обично се везује за менаџмент који настоји да обмане екстерна лица. Сврха лажног финансијског извештавања је да се финансијски положај, успешност и новчани токови компаније прикажу другачијим него што заиста jecy.

Предмет истраживања у раду су показатељи превара (знакови упозорења) уочљиви из финансијских извештаја компанија у Републици Србији. Циљ истраживања је да се испита да ли постоје показатељи превара у финансијским извештајима и који су најучесталији.

Показатељи превара (знакови упозорења) у финансијским извештајима важни су симптоми који говоре да постоји могућност да су извештаји лажни. Након што се они уоче, не треба извући закључак да је превара извршена, већ само да треба спровести дубље истраживање које треба да потврди или оповргне превару. Правовременим реаговањем на знакове упозорења могу се ублажити последице превара. На преваре у финансијском извештавању могу указати бројни симптоми, при чему се истраживање у раду заснива на уочавању аналитичких аномалија.

Методолошку основу истраживања у раду чини Beneish-ов модел, који се заснива на индексима којима се мере промене позиција финансијских извештаја. Модел је осмишљен на основу финансијских извештаја састављених у складу са GAAP CAД, што представља битно ограничење у контексту истраживања у овом раду. Друго ограничење везано је за недовољну поузданост модела у ситуацијама када иста компанија у низу узастопних година саставља лажне финансијске извештаје. Треће ограничење је у томе што се помоћу модела само препознају промене, али не може да у потпуности осветли узроке тих промена. Он може указати на превару и када она не постоји.

Истраживање у раду спроведено је на узорку од 42 привредна субјекта различите величине и делатности, а на основу њихових финансијских извештаја за 2013. и 2014. годину. Откривен је немали број знакова упозорења на преваре. 


\section{8}

Истраживање указује на умерен општи ризик од превара. Задуживање компаниja је значајан извора тог ризика. Уочен је и општи ризик од манипулисања са признавањем прихода. Код значајног броја предузећа уочен је висок ризик од манипулисања обрачунским ставкама уопштено и посебно амортизацијом. Пораст учешћа административних трошкова, такође, указује на висок ризик у значајном броју случајева. Резултати истраживања указују на то да је код производних предузећа и финансијских институција ризик од превара већи него код трговинских и услужних предузећа, али ово откриће треба посматрати са великом резервом, због ограничења Beneish-овог модела, која нарочито долазе до изражаја у случају финансијских институција. Ризици од превара у вези са капитализовањем трошкова и растом прихода од продаје већи су код великих него код малих и средњих предузећа. Ризик од превара са капитализовањем трошкова већи је код акционарских друштава него код друштава са ограниченом одговорношћу.

Истраживање указује на то да постојећи нивои контроле квалитета финансијског извештавања у Републици Србији, које превасходно чине интерна и екстерна ревизија, нису довољни и да је потребно успоставити додатне нивое контроле са форензичким рачуновођама, истражитељима превара и форензичким ревизорима као носиоцима. 